\title{
Petro-Economy and Corruption in Nigeria: Issues, Challenges and Lessons for the Future
}

\author{
Philips 0. Okolo \\ Department of Political Science, Faculty of the Social Sciences \\ Niger Delta University, Wilberforce Island, Bayelsa State, Nigeria. \\ Ambily Etekpe, PhD \\ Department of Political Science \\ Niger Delta University, Wilberforce Island, Bayelsa State, Nigeria.
}

\begin{abstract}
The cases of corruption in Nigeria have increased considerably since the oil boom in 1973. The World Bank, for example, reported in 2007 that, 'corruption is endemic in Nigeria and the bane of the country's socio-economic development'. The Transparency International (TI) Corruption Perception Index (CPI) also ranked Nigeria in 2010 as 134 out of 178 most corrupt countries in the world. The consensus is that corruption remains one of the most urgent and persistent challenges to Nigeria's socio-political stability with grave consequences on the sustainable development of minorities in Nigeria. The federal government rose to this challenge and established the Economic and Financial Crimes Commission (EFCC) and the Independent Corrupt Practices and related offences Commission (ICPC) to fight and conquer it, but these has not significantly addressed the situation. This paper therefore, sets out to examine the nature, determinants, manifestations and beneficiaries (collaborators / perpetrators) of petro-economy corruption, as well as measure its impacts on the national economy, governance and society. This is expected to produce new knowledge for multiple constituencies for sustainable development in Nigeria to formulate pro-active public policies. Against this background, the paper adopts the Marxist political economy theory on 'primitive accumulation of wealth' to explain why Nigerians indulge in petroeconomy and related corrupt practices to the detriment of minority rights and applies secondary method of data collection. The study finds that there is a strong linkage between economic factors and corruption. Hence, the paper recommends measure, particularly the establishment of special courts to stamp out petro-economy corruption in Nigeria.
\end{abstract}

Keywords: corruption, criminal-prosecution, "Dutch disease", excess-crude-oil" mismanagement, oil-bunkering.

\section{INTRODUCTION}

The metaphor corruption has several meanings. For Nuhu Ribadu, pioneer Chairman of Economic and Financial Crimes Commission (EFCC), "corruption is an abuse of public office for private gains" (Jega, 2005:10). The concept "Corruption" like many other concepts in social sciences has no settled meaning. This means that there is no straight backed definition, or generally accepted, or encompassing definition for the term corruption. 
However, certain definitional attempts have been proffered by different scholars. Although, there is often difficulties in defining it, because it means not only different things to different people, and even to the same people different things at different times, but also sanctions usually are attached to corrupt practices which hides them and gives them subtle forms. Thus, some people see "corruption" as a conscious and well planned act by a person or group of persons to appropriate by unlawful means the wealth of another person or group of persons. Then to others, it is the act of turning power and authority to ready cash.

For Agbese (1982), "corruption is a phenomenon so difficult to define, yet it percolates every structure of the society. It affects the military as well as it soils the hands of the civilians". He went further to define corruption as follows ...

When we use our position in society to secure certain advantages jumping a queue, being waved off at the checkpoint or making others bend the rules to accommodate our demands ... by whatever means even if it is just 'thank you' our action however innocent, however well-intentional, however unthreatening to others, has corrupted a system or a convention or some rules and regulations in application.

In this regard, even whatever form of seasonal gifts, free air tickets, lunch or diner - "kola" is no longer exempted, since these are likely to influence future courses of action and transactions the giver or receiver is thus corrupting protocol or breaching some rules and regulations in the society (Nigeria) etc. Professor Abdullahi, Smith, for instance saw "corruption as the diversion of resources from the betterment of the community to the gain of individuals at the expense of the community". Mumullan (1961: 183 - 4) point out that a public official is corrupt if he accepts money or money's worth for doing something that he is under a duty to do or to exercise a legitimate discretion for improper reason. Then for Malam Adamu Ciroma, corruption is "the deliberate binding of the system to favour friends or hurt foes, any misbehaviour deviation from or perversion of the system, or misleading Nigerians or giving them wrong or distorted information about things they ought to know."

Thus, any act or behaviour or omission, committed, internationally or not to influence the actions of another, the influential and the influenced, respectively has corrupted a system which is detrimental to the entire society (Okolo \& Akpokighe, 2014:30-38). In another perspective, the political science school sees "corruption" as "an optimal means of bypassing the queues and bureaucratic inertia and hence conducive to economic growth". While the economics school like Krueger (1974), saw "corruption" as "an external manifestation of rent seeking behaviour on the part of individuals."

Henley (2003), on the other hand, defines it as "misuse of private or public funds, office, power and/or position for private benefits". In the light of our experience, we shall adopt the United Nations Human Development (UNHD) report that defines corruption as:

Acceptance of money or other rewards for awarding contracts, violations of procedures to advance personal interests, including kickbacks from development programmes or multinational corporations; pay-offs for legislative support; and the diversion of public resources for private use, to overlooking illegal activities or intervening in the justice process. Forms of corruption also include nepotism, common theft, overpricing, establishing non-existent projects, payroll padding, tax collection and tax assessment frauds (UNHD Report, 1998:11).

This definition is all encompassing and relates to petro-economy corruption in Nigeria. 
It should be emphasized that this paper is not on corruption, in its entirety. Instead, it deals with only one aspect of it, i.e. petro-economy corruption (PEC). The PEC is concerned with mismanagement and outright stealing of funds from oil and gas sector of the Nigerian economy. These, as reflected in Tables 1 - 8, range from the demand of payment of 10 percent for the award of contracts in the First Republic; sales of oil at concessionary prices to some African countries, over-invoicing, under-reporting of petroleum revenue and embezzlement during the military era; to the Halliburton scam, unaccounted proceeds from excess crude oil production, fuel subsidy and fraudulent award of oil blocks in the Third and Fourth Republics( Aluko, 1976; and Biersteker and Lewis, 1999). These corrupt practices had debilitating effects on the national economy and development (Ujomu, 2000).

The paper wishes to debunk two prevailing wrong impressions about PEC, in particular, and corruption in general. First, is the argument that corruption in Nigeria is attributable to the colonial rule or neo-colonialism (Akinkuotu, 2005:33-6). Even if colonial rule was a factor, such an argument is now obsolete. This is because the cases of PEC investigated and charged to courts in Nigeria as could be seen in Tables 1, 5, 6 \& 8 were committed by high profile Nigerians, especially the petty bourgeoisie (i.e.; political class, bureaucrats and business tycoons). This peaked during the administration of former Nigeria's President Olusegun Obasanjo between 1999 and 2007, when it became both an art and deitified (Onabanjo, 2009:58-9).

Second, that poverty is the root cause of PEC in Nigeria. This, too, is not true; rather, corruption is the cause of poverty in Nigeria. This is premised on the logic that if poverty is the root cause of PEC, what can be said for the justification of the petty bourgeoisie listed in Tables $1,4 \& 8$ who by every standard are not poor, and yet, stole money from the public coffers? What therefore fuels PEC in Nigeria is greed (Bayart, 1993).

Nigeria is not the only oil producing country in Africa or the world. But the country has one of the worst cases (manifestations) of how oil wealth has either been out rightly stolen or mismanaged to the tune of US $\$ 400$ billion since independence in 1960 (Ogundele and Unachukwu, 2012). This must have informed Ribadu to refer to oil wealth as the devil's excrement or the Dutch disease.

Granted PEC is a global problem that is not peculiar to Nigeria as the world looses about US $\$ 4,000$ or 10 percent of its gross economic output per day, Global Financial Integrity estimates that between 1970 and 2010, Africa lost more than US\$854 billions to corruption. The Transparency International (TI) puts the amount of bribe companies paid politicians and other public officials in developing and transiting economies annually at US $\$ 40$ billion; and that Nigeria, in particular, and Africa, in general, constituted major part of it (Ogundele and Unachukwu, 2012, and Isakpo, 2013:52-3).

But the point of departure is the degree or pervasiveness which varies from country to country, and the measures each country has adopted to minimize, if not eradicate it. This is where the Nigerian situation discussed in five parts in this paper, becomes a matter of concern. The concern has raised several questions, such as, how did we arrive where we are today? Have we always been corrupt? What are the reasons and who were the collaborators, perpetrators or characters responsible for it? Are they still with us and/or involved in the pillaging of our crude oil (commonwealth)? What decisive steps do we need to take to flush out PEC in Nigeria? The questions are endless but the paper has addressed some critical ones central to this work. 
The paper aims at examining the nature, determinants, and beneficiaries (that is, Nigerian leaders) of PEC, and measures its catastrophic effects on the nation's economy and development. The essence is to produce new knowledge for multiple constituencies to formulate proactive policies for the eradication of corruption to engender sustainable development in Nigeria. The paper is divided into five major parts, beginning with this introduction. It is followed by an in-depth analysis of theoretical issues and six cases. Thereafter, it discusses the effects, measures, challenges and lessons for the future. It is rounded off with concluding remarks and recommendations to minimize, if not completely stamp-out PEC in Nigeria.

\section{Theoretical framework:}

\section{THEORETICAL ISSUES AND SELECTED CASES}

The paper adopts the Marxist economic theory of "primitive accumulation of wealth" to explain why highly placed Nigerians in the public and private sectors are indulged in PEC (Fatogun, 1979). The framework supports an earlier argument that poverty is not the root cause of corruption because there is a penchant for the 'rich to get richer'. That is why, Ajani (2003:15), has established a strong correlation between primitive accumulation and the 'conspiracy theories'. The conspiracy theories, like primitive accumulation, flourish in Nigeria because the petty bourgeoisie conspire to feast on public coffers. Thus, the six cases of primitive accumulation discussed below are "no more than a climax in a long drawn battle between the rulers and the citizens, the patriotic and the hegemonists, the mischievous and the uprights...." (Ajani, 2003). The issue at stake is that corruption has made the gap between the rich and the poor wider.

The paper applies secondary method to generate the data. The method, included government gazettes, specialized publications, journals and internet. This was complemented by participant's (i.e. author's) observation, especially during the National Assembly public hearings, participation in several public protests and discussions at state and national fora(Etekpe, 2009c and Adelagan, 2009). The cases are aggregated into six major areas and presented in Tables 1 - 8.

\section{Selected Cases (Manifestations) of PEC}

\section{a) The Halliburton Scandal}

Halliburton, the United States' (US) energy giant that was formerly run and still largely influenced and controlled by Dick Cheney, US Vice President, has a history of fraudulent business activities. It, for example, grossly over charged the US government US $\$ 27.4$ million for meals supplied to military personnel in Iraq in 2006. This followed the discovery of another bribery case of US\$6.3 million for fuel purportedly delivered to military bases in Iraq and Kuwait between 2001 and 2002. These glaring cases of graft and bribery are outrageous, but nothing to compare with the "US $\$ 180$ million paid as bribe to Nigerian government officials in its bid to win the contract of constructing the Nigerian Liquefied Natural Gas (NLNG) in Bonny, Rivers state, Nigeria" (Akinbi, 2003:123-31).

The bribery, coordinated by Halliburton, involved the consortium of four companies (that is, TSKJ) that eventually carried out the construction of NLNG. TSKJ is an accronomy for - Technip (France), Synamprogette (Italy), KBR of Halliburton Group (US) and Japan Gasoline Corporation. It (TSKJ) engaged two consulting companies - Tri-Star Investment Ltd (TSIL) and Marubeni Inc to bribe Nigerian "officials of the executive arm of government, Nigerian National Petroleum Corporation (NNPC), NLNG and leaders of the ruling political party (Peoples Democratic Party - PDP)" (May, 2003). While Tri-Star was to bribe senior officials with US $\$ 130$ million, Marubeni was to do same to junior officials with US\$50 million. Albert Jackson 
Stanley, Chief Executive Officer (CEO) of KBR, handpicked by Dick Cheney, US Vice President, allegedly struck an agreement with former Nigeria's military head of state and government, late General Sani Abacha for the construction of NLNG Trains 1 and 2 to TSKJ in August 1994. KBR then worked out a programme of what it called, "down loading and off loading of payments through subcontractors and vendors" (May, 2007). The Nigerian point man was Dan Etete, the then Nigeria's Minister of Petroleum Resources.

On 02 November 1994, officials of TSIL and Dan Etete met in Abuja, Nigeria, to discuss and agree on modalities for disbursing US $\$ 130$ million, and how Sani Abacha should get US\$40 million and the remaining US\$90 million shared among the rest of the officials. Out of the remaining amount, Dan Etete got US\$63,000. According to Houston Chronicle (2004), Dick Cheney then 'rushed' to Abuja, Nigeria, to consummate the deal of US $\$ 3.5$ billion.

A major challenge at that point in time was unfettered access to Sani Abacha, and MD Yusuf, a one time Inspector -General of Police (IGP), who later became the Chairman of NLNG, was handy. Corporate Crime Report (2004) alleged that US\$75,000 was then "downloaded for him (MD Yusuf) in two installments".

Having succeeded, TSKJ became interested in the construction of Train 3 and opened another round of discussion with Sani Abacha in May 1997. As the discussion progressed to an advanced stage, Sani Abacha died and was succeeded by General Abdulsalami Abubakar on 08 June 1998. Abduisalami. Abubakar was also alleged to have discussed with Halliburton on 28 February and 05 March 1999, and subsequently approved the contract at US $\$ 1.2$ billion. Thereafter, the sum of US\$32.5 million was released for the senior Nigerian officials who facilitated the award. Out of this amount, US\$2.5 million was allegedly off loaded into A. Abubakar's Swiss Bank Account.

The transaction spilled-over to Obasanjo's era, and he allegedly nominated Jackson Gaius Obaseki, who then met with officials of TSKJ in London on 20 December 2001. The company eventually won the contract worth US\$3.6 billion in March 2002, and 'downloaded' US\$51 million to Nigerian officials for the award (Adesomoju, 2012).

In August 2002, the deal took another dimension to involve the political bigwigs of the ruling party, PDP. For this purpose, TSKJ awarded a US\$50 million subcontract to Intels Energy Ltd (IEL), and 'downloaded' the amount through Citibank Nigeria, Plc. The company then became the new conduit pipe in bribing the politicians and "lower officials in NNPC and NLNG" (Table 1). Table 1 has highlighted selected cases of PEC from the discredited First Republic and military era to the Fourth Republic by highly placed Nigerians. Each of the seven different Nigerian leaders during this period has varying degree of PEC. 
Table 1: Selected Cases of Petro-Economy Corruption in Nigeria

\begin{tabular}{|c|c|c|c|c|c|}
\hline $\begin{array}{l}\mathbf{S} \\
\text { / } \\
\mathbf{N}\end{array}$ & $\begin{array}{c}\text { Period / } \\
\text { Administration }\end{array}$ & Nature & Amount & $\begin{array}{l}\text { Alleged Key } \\
\text { Personality }\end{array}$ & Remarks \\
\hline \multirow[t]{3}{*}{1} & \multirow{3}{*}{$\begin{array}{l}1960-1966 \\
\text { Nnamdi Azikiwe / } \\
\text { Tafawa Balewa, } \\
\text { First Republic }\end{array}$} & $\begin{array}{l}\text { Over Invoicing of imports and fraudulent } \\
\text { inflation of national debt part-financed from } \\
\text { oil }\end{array}$ & \multirow{3}{*}{$£ 2.5$ million } & - Festus Okotie Eboh & \multirow{3}{*}{$\begin{array}{l}\text { Foundation of } \\
\text { financial mis- } \\
\text { management / } \\
\text { economic } \\
\text { corruption }\end{array}$} \\
\hline & & African Continental Bank Scandal & & & \\
\hline & & $\begin{array}{l}\text { Corruption resulted from the import- } \\
\text { substitution (dependence) industries }\end{array}$ & & - Nnamdi Azikiwe & \\
\hline \multirow[t]{3}{*}{2} & \multirow{3}{*}{$\begin{array}{l}1967-1975 \\
\text { Yakubu Gowon, } \\
\text { Military Head of State } \\
\& \\
\text { Government (HOS\&G) }\end{array}$} & $\begin{array}{l}\text { Sold crude oil at concessionary prices to some } \\
\text { African States }\end{array}$ & \multirow{3}{*}{$£ 35$ million } & \multirow{3}{*}{$\begin{array}{l}\text { - Joseph Tarka } \\
\text { - Joseph Gomwalk \& } 9 \\
\text { Military Governors } \\
\text { - Ministry of Defence } \\
\text { - Obafemi Awolowo }\end{array}$} & \multirow{3}{*}{$\begin{array}{l}\text { Emergence of } \\
\text { millionaires } \\
\text { from petro- } \\
\text { economy } \\
\text { corruption }\end{array}$} \\
\hline & & $\begin{array}{l}16 \text { million tons cement scandal to build } \\
\text { military barracks }\end{array}$ & & & \\
\hline & & Over inflated contracts & & & \\
\hline \multirow[t]{4}{*}{3} & \multirow{4}{*}{$\begin{array}{l}1979 \text { - } 1983 \\
\text { Shehu Shagari, } \\
\text { Second Republic }\end{array}$} & $\begin{array}{l}\text { Payment of } 10 \text { percent for the award of } \\
\text { contract as a condition precedent to such } \\
\text { awards }\end{array}$ & $\$ 12$ billion & $\begin{array}{l}\text { Umaru Dikko \& Other } \\
\text { Key Ministers }\end{array}$ & \multirow{4}{*}{$\begin{array}{ll}\text { Corruption } & \\
\text { became } & \text { the } \\
\text { dominant } \\
\text { feature } \\
\text { Nigeria }\end{array}$} \\
\hline & & $\begin{array}{l}\text { Oil gate - misappropriation of oil sales } \\
\text { revenue overseas }\end{array}$ & \#2.8 billion & Muhammadu Buhari & \\
\hline & & $\begin{array}{l}\text { Amount for import bill siphoned out of } \\
\text { Nigeria }\end{array}$ & $\# 11.9$ billion & $\begin{array}{l}\text { Umaru Dikko, Bisi } \\
\text { Onabanjo and Adamu } \\
\text { Attah }\end{array}$ & \\
\hline & & Over invoicing of imports & $\# 0.57$ billion & Jim Nwobodo & \\
\hline \multirow[t]{3}{*}{4} & \multirow{3}{*}{$\begin{array}{l}1985 \text { - } 1992 \\
\text { Ibrahim Badamasi } \\
\text { Babangida (IBB), } \\
\text { HOS \& G }\end{array}$} & $\begin{array}{l}\text { Diversion of proceeds from sales of oil during } \\
\text { Gulf war, } 1990-1991\end{array}$ & $\$ 12.2$ billion & \multirow{3}{*}{$\begin{array}{l}\text { - P. Okongwu } \\
\text { - Paul Ogwuma } \\
\text { - 20 Separate banks } \\
\text { - IBB }\end{array}$} & \multirow{3}{*}{$\begin{array}{l}\text { Corruption } \\
\text { became } \\
\text { epidemic }\end{array}$} \\
\hline & & Underreporting petroleum revenue in 1990 & \#2.1 billion & & \\
\hline & & Debt -buy-back process & \#6 billion & & \\
\hline 5 & $\begin{array}{l}1994-1998 \\
\text { Sani Abacha, HOS \& G }\end{array}$ & $\begin{array}{l}\text { Halliburton scam involving TSKJ bribe for the } \\
\text { award of contracts for construction of NLNG } \\
\text { trains } 1,2 \& 3\end{array}$ & $\begin{array}{l}\text { US } \$ 180 \text { million } \\
\text { ( } \$ 11.70 \text { billion) }\end{array}$ & $\begin{array}{l}\text { - Dan Etete } \\
\text { - Tesler Stanley } \\
\text { - Tri-Star (TSKJ) } \\
\text { - Ibrahim Aliyu } \\
\text { - Abdullahi Bello, etc }\end{array}$ & $\begin{array}{l}\text { Corruption was } \\
\text { internationalized }\end{array}$ \\
\hline \multirow[t]{5}{*}{6} & \multirow[t]{5}{*}{$\begin{array}{l}1999-2007 \\
\text { Olusegun Obasanjo } \\
\text { (OBJ), } \quad \text { Fourth } \\
\text { Republic } \quad\end{array}$} & $\begin{array}{l}\text { Oil bunkering involving MT African Pride, OBJ } \\
\text { ordered the release of the Russian pirates and } \\
\text { disappearance of MT African Pride from } \\
\text { Nigerian territorial waters }\end{array}$ & - & $\begin{array}{l}\text { Tafa Balogun, } \\
\text { retired Inspector - } \\
\text { General of Police } \\
\text { - Vice Admiral } \\
\text { Sunday Afoloyan } \\
\text { - Funso Kupolukun etc }\end{array}$ & \multirow[t]{5}{*}{$\begin{array}{l}\text { Taking PEC to a } \\
\text { height } \\
\text { unsurpassed in } \\
\text { the history of } \\
\text { Nigeria. }\end{array}$} \\
\hline & & Fuel subsidy scam & $\begin{array}{l}\text { N49.50 } \\
\text { (US\$ 3) billion }\end{array}$ & Gaius Obaseki & \\
\hline & & Sales of oil blocks & - & \multirow{2}{*}{$\begin{array}{l}\text { OBJ, Gaius Obaseki, } \\
\text { Funso Kupolukun }\end{array}$} & \\
\hline & & $\begin{array}{l}\text { Unaccounted proceeds from excess crude oil } \\
\text { production }\end{array}$ & $\# 515.07$ billion & & \\
\hline & & $\begin{array}{l}\text { Money collected to settle salaries / } \\
\text { allowances of National Assembly Aides }\end{array}$ & \#0.376 billion & $\begin{array}{l}109 \text { Senators and } \\
366 \text { Reps of National } \\
\text { Assembly }\end{array}$ & \\
\hline 7 & $\begin{array}{l}2008-2012 \\
\text { Umaru Yar'Adua \& } \\
\text { Goodluck } \quad \text { Ebele } \\
\text { Jonathan, } \quad \text { Fourth } \\
\text { Republic }\end{array}$ & Fuel Subsidy Scam & $\$ 382$ billion & $\begin{array}{l}\text { - Patrick Ubah } \\
\text { - Ifeanyi Anosike } \\
\text { - Emma Morah } \\
\text { - Ngozi Ekeoma } \\
\text { (Tables 5, } 6 \text { \& 8) }\end{array}$ & $\begin{array}{l}\text { Triumph } \\
\text { corruption }\end{array}$ \\
\hline
\end{tabular}

Sources: Excerpt from D. Akinbi, 50 (2003:123 - 133) "Corruption in the Politics and Economy of Nigeria: Implications for National Development", Excerpt NJEH, Vols. 5 \& 6; and 2) Independent sources

The table also shows the specific nature, amount and perpetrators, as well as progression from anemic and epidemic to the present stage where corruption triumphs in the country. The principal shareholders of IEL were Atiku Abubakar and Shehu Musa Yar'Adua, former Nigeria's Vice President to Olusegun Obasanjo (1999-2007), and Chief of General Staff to General Yakuba Gowon (1967 - 1976). The scandal attracted the attention of US government and it interrogated Stanley who owned up his role and told the US Department of Justice that he:

met the then Nigeria's President, Chief Olusegun Obasanjo and the then Group Managing Director (GMD) of NNPC, Gaius Obaseki, in Abuja on 11 November 2001 to designate a representative with whom TSKJ should negotiate bribes in support of the award of trains 4 and 5 contracts (USCC 78dd-1) 
The foregoing analysis points to the fact that Halliburton succeeded because:

in Nigeria, like the US, the congealing of the state and the business world is developing to the point that small groups of individuals who control most of the nation's wealth are also the same individuals who hold the most powerful political offices within the state (May, 2007)

\section{b) The Nigerian National Petroleum Corporation (NNPC) Saga}

Ajaero (2008:14) describes the NNPC under former President Obasanjo, 1999 - 2007, as a "huge chamber of fraud and corruption". Most cases of the PEC were committed at the NNPC, Pipeline Products Marketing Company (PPMC) and Department of Petroleum Resources (DPR) through three major fronts, namely:

i. Deliberate increase in the daily quota of production as against the figures allocated to Nigeria by the Organization of Petroleum Exporting Countries (OPEC). The Presidency, along with NNPC and DPR then 'pocketed' the extra income, instead of paying it into the Federation Account;

ii. Diversion of interest on income from illegally transferred money from NNPC Joint Venture Account (JVA); and

iii. Diversion of money through a non-existent JVA cash call arrears.

The audit report of Hart Group, a British firm, brought to light these corrupt practices and queried:

why the refineries in 1999 and 2000 received more crude oil than was sent to the terminals and could not properly account for 22 million barrels of crude oil sent to them but did not get to the refineries during the years 2001, 2002, 2003 and 2004 (Ajaero 2008).

The audit report also revealed that for the period 1999 and 2002, OPEC gave Nigeria a specific production quota but it (NNPC) produced in excess of the quota, and "shared the excess proceeds" between the Presidency and NNPC. Based on the report, Etekpe (2009a:43-5) tabulated the level of corruption and presented in Table 2.

Table 2:Unaccounted Proceeds from Excess Crude Oil Production, 1999 - 2002

\begin{tabular}{cccc}
\hline Year & OPEC Prod Quota & $\begin{array}{c}\text { NNPC Actual } \\
\text { Production (Barrels) }\end{array}$ & $\begin{array}{c}\text { Excess Production } \\
\text { (Barrels) }\end{array}$ \\
\hline 1999 & $403,390,000$ & $499,774,775$ & $46,384,745$ \\
2000 & $748,011,000$ & $828,618,101$ & $80,601,101$ \\
2001 & $728,634,000$ & $863,835,184$ & $130,201,184$ \\
2002 & $478,851,000$ & $542,103,211$ & $54,252,271$ \\
\hline Total & & & $\mathbf{3 1 6 , 4 4 5 , 2 7 1}$ \\
\hline & Price @ US\$25 / barrel & & $\mathbf{N 5 1 5 , 0 7 1 , 7 8 4 , 4 6 0}$ \\
\hline
\end{tabular}

Source: Etekpe, A (2009a:43-5) "Policy Option and Adaptation: A Comprehensive study of the Niger Delta and other Deltas of World", Department of Political Science, Niger Delta University, Monograph Series No. 003.

Table 2 shows that the excess crude oil production rose from 46 million bpd in 1999 to 130 million bpd in 2001; and thereafter fell to 54 million bpd in 2002 for fear of sanction by OPEC. In all, the excess production for the 4 years stood at 316 million bpd, amounting to an excess of N515.07 billion that was out rightly stolen. 
Hamman Tukur, former Chairman, Revenue Mobilization, Allocation and Fiscal Commission (RMAFC), the monitoring agency of NNPC confirmed the high level of PEC in NNPC and the oil and gas industry when members of the Commission visited the former Nigeria's President Umaru Musa Yar'Adua in Aso Rock, Abuja. He told the then President that the Commission had found out that Nigeria lost N555 billion between December 2004 and April 2007 that would have accrued to the Federation Account or invested in human capacity and social infrastructural development in the Niger Delta and pointed out that while NNPC accounts for kerosene (DPK), petrol (PMS) and diesel (AGO), it does not account for the proceeds from the sales of oil and LPFO.

Worried by these high profile cases of PEC in NNPC, the House of Representatives (Reps) Committee on Petroleum and Downstream Industry (CPDI) probed the activities and operations of the corporation, along with its subsidiaries and DPR from 1999 to 2008. The CPDI, led by Igo Aguma as the Chairman, was upset with the statistical discrepancies between NNPC and its monitoring agencies, such as RMAFC and the Central Bank of Nigeria (CBN) on the areas of crude oil allocation, sales and proceeds arising from the remittance of same to the Federation Account:

The Committee found that the Obasanjo's government short-circuited all existing platforms for decent business transactions in NNPC, as well as the DPR and technically ran the nation's oil sector aground.... That the Obasanjo presidency took unholy meddling in the affairs, especially, the accounts of NNPC to criminal height throughout his 8 years tenure (Ajaero, 2008:18).

Earlier on 28 July 2003, EFCC had informed the Committee on the sharp practices in NNPC and the oil industry. The information alleged that Jackson Gaius Obaseki, former GMD of NNPC and Dan Nzelu, former Managing Director (MD) of PPMC had 'created a nest for themselves by conjuring up a scam. They sold petroleum products to marketers at the subsidized domestic price of N8.30 (US\$60) per litre and thereafter exported it at US\$165 / litre'. This deprived PPMC from officially making a gross income of US\$250 million for the government through legitimate exports.

Another large scale PEC in NNPC was the establishment of Escarvos Gas to Liquid Project (EGTL). It was alleged that the initial cost of the project was inflated by NNPC officials from N69.2 billion (US\$592 million) to N352 billion (US\$2.9 billion) in 2000 (Akinbi, 2003:128). This caused the delay in the commencement of the project; and by 2003, the cost had escalated to N819 billion and abandoned.

\section{c) Excess Crude Oil Sales}

The issue of excess crude oil sales and mismanagement of the proceeds earlier highlighted resurfaced again. This time, the aggrieved 16 states jointly filed a suit against the federal government at the Supreme Court on 05 May 2012. The federal government could not have its way and "entered into negotiation with the states over the disputed withdrawal of about N2.29 trillion from the Excess Crude Account (ECA) in order to settle out of court" (Alli, 2012:1,4 \& 59). The rationale of government is to forestall the case from negatively affecting the management of the Sovereign Wealth Fund (SWF) already floated from the ECA to the tune of US\$1 billion. The 16 states and their disputed amounts from ECA is displayed in Table 3. The Suit was necessitated by the fact that prior to it; the federal government had withdrawn N5.51 trillion from it (ECA) without consulting the states as required by the 1999 Nigerian Constitution (as amended). 
Table 3: Disputed Excess Crude Oil Account between Federal and State Governments 2012

\begin{tabular}{clr}
\hline S/NO & STATE & AMOUNT (N BILLION) \\
\hline 1 & Bayelsa & 300.00 \\
2 & Oyo & 100.00 \\
3 & Niger & 99.68 \\
4 & Edo & 99.26 \\
5 & Benue & 95.30 \\
6 & Abia & 93.09 \\
7 & Ogun & 84.07 \\
8 & Yobe & 82.55 \\
9 & Osun & 80.77 \\
10 & Ekiti & 74.31 \\
11 & Bauchi & 28.52 \\
12 & Kaduna & 108.30 \\
13 & Kogi & 86.21 \\
14 & Rivers & 385.58 \\
15 & Ebonyi & 74.73 \\
16 & Taraba & 84.98 \\
\hline
\end{tabular}

Source: Alli, Yusuf (2012:1 \& 4). "Peace Moves on N2.29 trillion Excess Crude Account". The Nation, August 29.

The grievances of the states were compounded by the revelation of Oby Ezekwesi, former World Bank Vice President for Africa, that "about US $\$ 400$ billion of Nigeria's oil revenue has been stolen or mismanaged since independence in 1960" (Ogundele and Unackukwu, 2012:61). She emphasized that whereas oil accounts for 90 percent of Nigeria's export commodity, 80 percent of the revenue ends up in the hand of 1 percent Nigerians - petty bourgeoisie.

Oby Ezekwesi's revelation corroborates with an earlier report by Omonode (2010:1) that:

The quantum of oil and gas produced in the country is not fully accounted for or used for the benefit of Nigerians, thereby making Nigeria a rich country but with poor people.... This is glaring as revenue derived from what is produced is not accurately recorded and paid into the Federation Account...

This staggering revelation on corruption was also extended to the sales or award of oil blocks (Nkechi, 2013:16).

\section{d) The Oil Block Sales}

The presidency interfered with the sales or award of oil blocks in 2005, 2006 and 2007. Instead of allowing officials of DPR to award oil blocks, Colonel Abubakar Umar (rtd), former military governor of Kaduna state, alleged that "President Obasanjo awarded himself and his cronies 70 percent of oil blocks through dubious processes" (Ajaero, 2008:21). Some of the beneficiaries (that is, companies and principal shareholders) of the oil blocks are displayed in Table 4 . Incidentally, they are highly placed companies and individuals in both private and public sectors. 
Table 4: Selected Beneficiaries of Oil Block Sales 2005 - 2011

\begin{tabular}{cll}
\hline S/NO & \multicolumn{1}{c}{ NAME OF COMPANY } & \multicolumn{1}{c}{$\begin{array}{c}\text { PRINCIPAL } \\
\text { SHAREHOLDERS }\end{array}$} \\
\hline 1 & A \& Hatman Ltd & Tony Anenih \\
2 & ERHC (Chrome Energy) & Emeka Offor \\
3 & Aliko Dangote Group & Aliko Dangote \\
4 & Transcorp (OPL 295) & Olusegun Obasanjo \\
5 & Jigawa State Government & Saminu Turaki \\
6 & Radiant Oil & Adamu Muazu \\
7 & Filtim-Huzod Oil \& Gas & Hope Uzodima \\
\hline
\end{tabular}

The fraudulent oil block sales are understandable because NNPC and DPR contracts during Obasanjo tenure were not subjected to due process. He equally revoked oil blocks, such as OPL 246 of South Atlantic Petroleum Company, owned by Theophilus Danjuma, former Defence Minister and his (Obasanjo) Chief of Staff, when they parted ways due to Danjuma's anti-third tenure stance against Obasanjo. The OPL 246 was under litigation at the federal high court, Lagos, Nigeria up to 2012 but has since been given back to its owners.

\section{e) Oil Bunkering and the MT African Pride}

"Nigeria lost about 180,000 barrels of crude oil per day, amounting to US\$7 billion per year, to bunkers" (Anucha, 2012:10). This form of PEC is promoted by a cartel of Nigerians in collusion with foreigners. By June 2012; the Joint Military Task Force (JTF), arrested 33 pirates and destroyed 112 illegal refineries in the Niger Delta. Those apprehended were transferred to the Nigerian Security and Civil Defence Corps for further investigation and prosecution (Anucha, 2012). The number of arrests has increased over time from 2012 to 2014.

A celebrated case in this regard is the MT African Pride. The vessel, MT African Pride, was used by Russian pirates, in collusion with some Nigerians, possibly owners of oil blocks, to bunker 15,000 cubic litres of crude oil from the Niger Delta. It was caught and seized by the Nigerian Navy in 2004. "When the vessel was arrested", Funso Kupolukun, former GMD, NNPC told the House of Reps Committee that probed the sudden disappearance of the vessel and pirates on 14 September 2004, "I got approval from President Obasanjo to evacuate 6,000 cubic litres of crude oil from the vessel". He went further to state that the crude oil was even contaminated and sold at a subsidized rate of US\$24 per barrel as against US\$47 per barrel at international market. The proceeds were then paid into the Federation Account.

"But these facts", as Uwugiaren (2004:28-30) posits, "were conflicting with the findings of Tony Aziegbemi led Committee that probed the matter". First, the Committee found that the proceeds were under declared because the vessel carried 15,000 cubic litres as against 6,000 cubic litres that was reported. Second, when the vessel was under the custody of the Nigerian Navy, it invited experts from Shell Petroleum Development Company of Nigeria (SPDC) Ltd to analyze the quality of the crude oil; and SPDC reported that it was not contaminated. Third, there was no evidence that the proceed was paid into the Federation Account as stated by Kupolukun. Finally, the Presidency, NNPC and the Navy were indicted in the disappeared MT African Pride, and the conspiracy was extended to petroleum support fund (fuel subsidy).

\section{f) The Fuel Subsidy Scandal}

The foregoing analyses seem like an ice berg when compared with the fuel subsidy scam that erupted in Nigeria in January 2012. Nigeria is the 6th largest crude oil exporters in the world, but decades of corruption and mismanagement have left the people dependent on imported refined fuel. Thus, the government subsidies and this has become the single highest fiscal cost to the tune of N1.24 trillion per year between 2011 and 2012 alone, the federal government 
spent N3.7 trillion on fuel. President Goodluck Ebele Jonathan could not continue with it and removed the fuel subsidy, raised the pump price to N140 per litre, and reduced the fuel importers from 148 to 38 in January 2012. This prompted an instant reaction from Nigerians who went on strike/protest for over a week before the government and the people agreed on a compromised price of N97 per litre (Olawuni, 2013:6).

The House of Reps Adhoc Committee on Fuel subsidy, chaired by Farouk Lawan, investigated the matter and indicted 71 (G.17) high profile companies, along with their principal shareholders. The report stated that the G.17 "jointly collected N230.184 billion on PMS volume of 3,262,964,225 litres of fuel that was not supplied" (Agbaegbu, 2012:13). In presenting the report for debate in the House of Reps, Farouk Lawan said:

Claims made by the G.71 could not be verified as depots into which they purportedly discharged the products could not confirm receipts.... In some instances, there were wide gap between the dates the importer claimed to have discharged its products and the date receipt was confirmed from the depot. Some claims to volumes discharged made by some of the marketers differed significantly from the volume received at depots (Agbaegbu, 2012:13).

Based on the findings, the Committee stated that the various acts committed by the companies amounted to infractions, which are 'not sustainable and, therefore, should be refunded'.

After due consideration by the House of Reps, the report was sent to the anti-graft agencies, namely: EFCC and ICPC for further investigations and prosecution. Table 5 has listed the indicted companies, volume of disallowed litres of fuel and amount. It is instructive to note in Table 5 some of the high profile Nigerians and their companies involved in the scandal. They, include:

i. Stella Adah Oduah - Minister of Aviation - Sea Petroleum \& Gas;

ii. Abdulsalami Abubakar - former Head of State and Government - Maizube Petroleum Ltd;

iii. Emmanuel Iheanacho - former Minister of Interior - Integrated Oil and Gas Ltd;

iv. Christopher Kolade - prominent technocrat, former Managing Director of Cadbury Nigeria Plc and Acorn Petroleum Ltd; now Chairman of Subsidy Reinvestment Empowerment Programme (Sure-p);

v. Chika Alex Okafor - renowned industrialist - A - Z Petroleum Products Ltd;

vi. Patrick Ubah - industrialist - Capitol Oil and Gas Ltd; and

vii. Aig-Imoukhuede - Managing Director of Access Bank Plc - Ice Energy Petroleum Trading Ltd. 
Table 5: Disallowed Claims to Discharges and Subsidy, 2010 - 2011

\begin{tabular}{|c|c|c|c|}
\hline S/No & Name of Marketers & $\begin{array}{c}\text { Volume } \\
\text { Deductable } \\
\text { Litres - NNPC }\end{array}$ & $\begin{array}{c}\text { Subsidy } \\
\text { Refundable } \\
\end{array}$ \\
\hline 1 & Acorn Plc & $140,894,140$ & $8,514,900,513$ \\
\hline 2 & Alminnur Resources Ltd & $46,918,888$ & $2,543,800,931$ \\
\hline 3 & Anosike Group of Companies Ltd & $15,769,795$ & $1,318,443,555$ \\
\hline 4 & Ascon Oil \& Gas Company & $64,745,352$ & $4,451,932,090$ \\
\hline 5 & Avant Garde Energy & $19,470,988$ & $1,154,824,298$ \\
\hline 6 & A - Z Petroleum & $130,721,532$ & $8,065,557,648$ \\
\hline 7 & Cah Resources Association Ltd & 323,005 & $24,206,727$ \\
\hline 8 & Channel Oil \& Petroleum Ltd & $28,966,976$ & $622,518,071$ \\
\hline 9 & Crust Energy Ltd & $13,301,936$ & $1,192,651,581$ \\
\hline 10 & Downstream Energy Source Ltd & $39,341,145$ & $2,947,780,261$ \\
\hline 11 & Dozzy Oil \& Gas Ltd & $19,081,051$ & $1,587,298,801$ \\
\hline 12 & Duport Marine Ltd & $47,374,819$ & $3,555,127,358$ \\
\hline 13 & Eco-Regen Ltd & $38,060,916$ & $3,339,101,218$ \\
\hline 14 & Eurafic Oil \& Coastal Services Ltd & $42,442,180$ & $3,868,147,024$ \\
\hline 15 & First Deep Water Discovery Ltd & $12,244,946$ & $932,207,739$ \\
\hline 16 & Fradro International Ltd & $45,080,707$ & $3,661,643,268$ \\
\hline 17 & Fresh Synergy Ltd & $19,350,390$ & $1,417,029,059$ \\
\hline 18 & Heyden Petroleum & $40,441,260$ & $3,345,455,733$ \\
\hline 19 & Ibafon Oil Ltd & $20,134,910$ & $1,474,479,459$ \\
\hline 20 & Imad Oil \& Gas Ltd & $40,621,597$ & $2,701,002,852$ \\
\hline 21 & Integrated Oil \& Gas Ltd & $190,846,561$ & $13,252,055,429$ \\
\hline 22 & Integrated Resources Ltd & $13,395,101$ & $1,166,486,995$ \\
\hline 23 & Ipman Investment Ltd & $113,252,677$ & $7,538,589,178$ \\
\hline 24 & Knightsbridge & $62,705,372$ & $1,685,869,439$ \\
\hline 25 & Linetrale Supply \& Trading Company & $18,015,790$ & $1,213,913,930$ \\
\hline
\end{tabular}

Source: Agbaegbu, Tobs (2012:14). "Indicted Companies and Their Owners", Newswatch, July 23.

Apart from G.17, there were 13(G.13) other companies that Lawan's Committee identified. They include: Business Ventures Ltd, East Horizon Gas Company Ltd and Index Petroleum Africa shown in Table 6. Table 6 reflects names of marketers, the periods, and amounts defrauded and expected to be refunded to the federal government to the tune of US $\$ 283,244,731$ and US\$64,767,764 in 2010 and 2011, respectively.

It is worth pointing out that the oversight function of the legislature is to provide the necessary supervision and control of affairs in the oil and gas sector in Nigeria. "But", as Agbo (2012:45) puts it, "from 1999 to date, the National Assembly has turned the powers (of oversight function) into nightmare of deception, corruption and hypocrisy... that have limited their performance since the return of democracy in 1999". This, as shown in Table 7, ranged from power, capital market, NNPC, sales of federal government houses in Lagos and Abuja to fuel subsidy. It behooves the leadership of the National Assembly to fight corruption to engender national development. 
Table 6: Companies which obtained Foreign Exchange but did not Import Petroleum Products

\begin{tabular}{llcc}
\hline S/No & Name of Marketers & 2010 US\$ & 2011 US\$ \\
\hline 1 & Business Ventures Nigeria Ltd & $22,927,340$ & - \\
2 & East Horizon Gas Co. Ltd & $20,735,911$ & - \\
3 & Emadeb Energy & $6,606,094$ & - \\
4 & Serene Petroleum \& Gas Ltd & $232,975,385$ & - \\
5 & Carnival Energy Oil Ltd & - & 51,090 \\
6 & Crownlines & - & $4,756,275$ \\
7 & Ile Energy Petroleum Trading Ltd & - & $2,131,166$ \\
8 & Index Petroleum Africa & - & $6,438,850$ \\
9 & Ronad Oil \& Gas Ltd West Africa & - & $4,813,272$ \\
10 & Severe Greenfield Ltd & - & $4,813,361$ \\
11 & Supreme and Mitchelles & - & $16,947,000$ \\
12 & Tridax Energy Ltd & - & $15,900,000$ \\
13 & Zamson Global Resources & $\mathbf{2 8 3 , 2 4 4 , 7 3 1}$ & $\mathbf{6 4 , 7 6 7 , 7 6 4}$ \\
\cline { 2 - 4 } & TOTAL
\end{tabular}

Source: Agbaegu, Toba (2012:15). “Indicted Companies and Their Owners”, Newswatch, July 23

Table 7: $\quad$ Lists of some National Assembly Probes, $2007-2012$

\begin{tabular}{lll}
\hline S/NO & YEAR & AGENCIES / INSTITUTIONS \\
\hline 1 & 2007 & House of Reps - Ministry of Finance \\
2 & 2008 & House of Reps - Energy sector \\
3 & 2008 & Senate - FCT Minister, El-Rufai \\
4 & 2008 & House of Rep - Railway Project \\
5 & 2008 & Senate - Jos Crisis \\
6 & 2008 & Senate - NIMASA and Shippers' Council \\
7 & 2008 & Senate - Ajaokuta Steel Company Concession \\
8 & 2008 & Senate - Ministry of Transport and Transport Sector \\
9 & 2008 & House of Reps - NNPC \\
10 & 2009 & House of Reps - Jos Crisis \\
11 & 2009 & House of Reps - Customs Scam \\
12 & 2009 & Senate - Obasanjo and Yar'Adua Solid Minerals Special Account \\
13 & 2009 & National Assembly - World Bank Aviation Loans \\
14 & 2009 & Senate-Federal Government Sales of Houses in Lagos and Abuja \\
15 & 2010 & Senate - Lead Poisoning in Zamfara State \\
16 & 2010 & House of Reps - Sale of Nigeria House in New York \\
17 & 2011 & House of Reps - Justices Salami / Katsina - Alu Face-off \\
18 & 2012 & Senate - Establishment and Public Service-Pension \\
19 & 2012 & Senate - Bureau of Public Enterprises (BPE) \\
20 & 2012 & House of Reps - Capital Market \\
21 & 2012 & House of Reps - Fuel Subsidy Scam \\
\hline
\end{tabular}

This resurfaced in the House of Reps when Farouk Lawan, Chairman of the Adhoc Committee that probed the fuel subsidy scandal, allegedly collected a bribe of US $\$ 620,000$ from Femi Otedola to 'tinker the report and exonerate him from complicity'. Farouk Lawan's case is not first; there had been bribe scandals of several probe panels in the National Assembly (Table 7).

\section{IMPACT ON NATIONAL DEVELOPMENT}

There is no doubt that PEC has impacted negatively on national security and development. According to Campbell (2010), Okolo (2011; 2014: 121-138); Okolo \& Akpokighe (2014: 99 109) "the Halliburton case, has militated against the country's drive for industrialization, and 
given the impression that only expatriate companies that have financial muscle will henceforth win juicy contracts in Nigeria. This, invariably means, there is no hope for local firms to grow".

The case of over bloated cost of EGTL is regrettable as it led to the abandonment of the project. The project is supposed to stimulate economic development in Nigeria by converting liquefied petroleum gas (LPG) to GTL diesel and naphtha for domestic and international markets.

The other area is that of the quantum and amount of oil bunkering in Nigeria has reached an unacceptable level. Presently, about US\$7 billion is lost every year to oil bunkering. This, in addition to the US $\$ 400$ billion oil revenue stolen or mismanaged since independence in 1960 has invariably led Nigeria to borrowing to finance capital projects that would have ordinarily been funded from the stolen money. Against this background, the domestic and external debts have added their own burden to the fragile economy (Bayart, 1993; Ayandiji, 2007 and Etekpe, 2012:17-34). Going forward, PEC has impacted negatively on the international image of Nigeria, up to 2012. "This", according to the CBN, "has prompted the aggregate foreign investment inflow to fall from US $\$ 4.75$ billion in 2011 to US\$3.44 billion in September 2012" (Komolafe, 2012:2). However, these has significantly improved safe for the downturn in oil prices towards the close of 2014.

The cumulative effects of PEC have negatively impacted on the country's Millennium Development Goals (MDGs) that will terminate just 3 years from now. In view of the high level of PEC as shown in Tables 1, 5, 6 \& 9, Nigeria does not have the money to fund MDGs target programmes. As Kumolu (2009:39) puts it:

The great expectation that accompanied the introduction of MDGs is fading in Nigeria.... How and why MDGs looks unrealistic in Nigeria remains a tormenting question. The 2004 report, which was Nigeria's first on MDGs, states that based on available information, it is unlikely that the country will be able to meet most of the goals by 2015, especially the goals related to eradicating extreme poverty and hunger....

This reason is attributed squarely to PEC - woven around highly placed actors in the public and private sectors, who are leading the country fast to the status of a failed state (Ibaba, 2013:12-23). It is, therefore, important that Nigerians should take decisive measures to challenge PEC with vigor and in accordance with the laws of the land.

In addition to the fore goings, PEC has serious implications on minority rights in Nigeria with grave consequences on development. This has become spectacular in unabated illegal oil bunkering in the minority area of Nigeria's Niger Delta. The country is losing an average of 350,000 barrels per day, amounting to US\$7 billion per year since 2010 from oil bunkering. PEC, along will oil bunkering/theft has reduced revenue accruing to the minority states, especially, Niger Delta states, resulting in deteriorating quality of life. Earlier, the Human Rights Watch reported in 1999 that "the Nigerian political economy has come to depend on a spectacular system of corruption, involving systematic kickbacks for the award of contracts, special bank accounts in the control of the presidency, allocation of oil or refined products... (All to the disadvantage of the oil producing minorities in southern Nigeria. Incidentally, this was the case of the Middle Belt minorities in Northern Nigeria in 1958 - 1966).

The report went further to state that corruption is encountered and driven by the activities of oil companies, private sector, and government. This has spurred Delta-wide social, political and economic conflicts over the years, beginning with Isaac Boro Saga in 1966, Ogoni debade in 1990, and organized military in 2004. The implications of these on security/conflicts are 
divided into factors that undermine peace and those that accelerate insecurity/conflicts in minority areas in Southern Nigeria (Niger Delta) in Table 8.

Table 8: Consequences of Endemic Corruption-security Nexus on Development of Minority Areas in Nigeria

\begin{tabular}{|c|c|c|}
\hline S/No & Corruption Undermining Peace & Corruption Accelerators of Insecurity \\
\hline 1 & $\begin{array}{l}\text { Erosion of the social fabric and social } \\
\text { disintegration }\end{array}$ & \\
\hline 2 & $\begin{array}{l}\text { Compromised rule of law and } \\
\text { government-oil companies quick-fix } \\
\text { strategy of conflict management } \\
\text { approach }\end{array}$ & $\begin{array}{l}\text { Perpetuation of poverty, inequality and } \\
\text { inequitable distribution of resources }\end{array}$ \\
\hline 3 & $\begin{array}{l}\text { Prevention of host communities from } \\
\text { legitimately benefiting from oil and oil- } \\
\text { related ventures in the region }\end{array}$ & $\begin{array}{l}\text { Political and economic marginalization that } \\
\text { leads to emergence of armed ethnic militias and } \\
\text { warlords. }\end{array}$ \\
\hline
\end{tabular}

Source: Culled from WAC Global Services Report, 2003:37

\section{MEASURES, CHALLENGES AND LESSONS IN FIGHTING PEC}

In an effort to fight PEC, in particular, and corruption, in general, the Nigerian government has established two anti-graft agencies - EFCC and ICPC. This is, in addition, to the statutory role of the Special Fraud Unit (SFU) of the Nigeria Police (NPF). The EFCC has since 2006 charged over 40 persons who misused their political positions (PEPs) to allegedly steal over N230 billion (Ayandyi, 2007).

The perpetrators of the Halliburton scam, that is, Ibrahim Aliyu (former Permament Secretary in the Office of Head of Service), retired Air vice Marshal Abdullahi Bello, and Mohammed Bakari of the Urban Shelter Ltd were arraigned before Justice Abubaka Umar, an Abuja High Court Judge, by EFCC. They faced a nine-count charge bordering on petro-economy corruption and bribery for using their companies - Intercellular Nigeria Ltd, Sherwood Petroleum Ltd and TSIL, to benefit from US $\$ 7.5$ million Halliburton bribe. Umar, however, struck out the suit on technical ground, that is, want of diligent prosecution" (Adesomoju, 2012).

Already, the Office of the Attorney-General of the Federation has revisited the case and filed a civil action against Halliburton Corporation towards getting compensation and restitution. It has started with Bounde Adeyanju, former Special Assistant to former President Obasanjo standing trial before an Abuja High Court. According to Dunia (2010), Adeyanju confessed to the police on 22 June 2009 that:

Sometime in 2002/2003 when the ruling party, PDP, was in crisis (resulting from the rift between Obasanjo and his deputy, Atiku Abubakar that affected the funding of the party), he approached Gaius Obaseki (former GMD, NNPC) among other people for financial assistance for the party... I then collected in three installments of US\$2 million, $\$ 1$ million and another $\$ 1$ million, respectively, and other disbursements were delivered to Alhaji Lawan Batagarawa, former Minister of Integration and Cooperation in the administration of President Obasanjo.

In his reaction, Lawan Batagarawa admitted on 30 June 2009 that, "I collected monies from Adeyanju between 15 to 20 times, totaling about N30 million..." (See Table 1). The SFU also remanded in police custody Dr. Patrick Ubah, MD of Capitol Oil and Gas Ltd for an alleged fifty 
six billion (N56b) naira fuel subsidy scam. The other employees of the company remanded with him were:

i. $\quad$ Nsikan Usoro, Head of Trading;

ii. Godfrey Okorie, Depot Manage;

iii. Chubuzor Ogbuokiri, General Manager - Operations; and

iv. Orji Anayo, Executive Director - Operations.

Abdukabir Aliu, Managing Director / Chief Executive (MD/CE) of Matrix Energy Ltd allegedly involved in N13.376 billion fraud was equally arraigned before a High Court in Lagos along with his employees - Yusuf Oyolola (Operations Manager) and Adewale Akinde (Accountant).

The EFCC has further arraigned 13 additional directors of oil marketing companies before Justices Habeeb Abiru and Lateefa Okunu in Lagos High Court in Ikeja for fuel subsidy fraud. They allegedly obtained the amounts listed against their names in Table 8 from the Petroleum Support Fund (PSF) for fuel not supplied. It was also alleged that all the defendants forged different bills of lading for PMS not supplied.

The major challenge facing PEC is said to be the speedy dispensation of justice and the governments political will to fight corruption because most of those involved are politically connected persons in the helms of affairs in Nigeria. On the judiciary aiding PEC, Farida Waziri, former Chairman of EFCC, decried on 08 June 2010 how the judiciary - courts, lawyers and judges, have frustrated the efforts of the commission through "frivolous adjournments and fraudulent injunction" (Agbo, 2010:16). She was not the only one that has complained. Justice Emmanuel Ayoola, onetime Chairman of ICPC and former Justice of the Supreme Court of Nigeria, made similar assertion that:

With the slow speed of the judiciary in the administration of criminal justice system, cases are stagnated at various courts across the nation since 2005. This suggests that the nation's criminal justice system has broken-down, and accounts for the reasons why politically exposed persons (PEPS) that are charged to court allegedly bribe judicial officers to make sure that their cases are never tried, knowing that they would eventually be found guilty and sent to jail. They then wriggle their way to freedom through incessant adjournments and perpetual injunctions against anti-graft agencies.... (Agbo, 2010).

Another challenge in fighting PEC is the reality that the entire jurisprudence can be tampered with on technical grounds in the full glare of the National Judicial Council. Thus, there are cases instituted more than 5 years ago that has not gone beyond the preliminary stages. The calculation is to keep the cases on the court shelves while waiting for a favourable political environment to completely kill them. This was the tactics of Justice Umar in the Halliburton's case. This is displayed in Table 9. 
Table 9: Selected Cases of Fuel Subsidy Fraud in Nigerian Courts, 2012

\begin{tabular}{|c|c|c|c|c|}
\hline $\begin{array}{l}/ \\
\mathrm{N}\end{array}$ & $\begin{array}{l}\text { Name of Principal } \\
\text { Shareholders / Company }\end{array}$ & Nature of the Case & Amount & $\begin{array}{l}\text { Action taken as } \\
\text { at } 30 \text { June } 2013\end{array}$ \\
\hline 1 & $\begin{array}{l}\text { Dr. Patrick Ubah } \\
\text { Managing Director (MD) } \\
\text { Capital Oils \& Gas Ltd }\end{array}$ & \multirow{2}{*}{$\begin{array}{l}\text { Obtaining money for fuel } \\
\text { not supplied }\end{array}$} & $\begin{array}{l}\text { A56 } \\
\text { million }\end{array}$ & \multirow{8}{*}{$\begin{array}{l}\text { Arraigned before } \\
\text { Magistrate and } \\
\text { High Courts in } \\
\text { Lagos and Abuja }\end{array}$} \\
\hline 2 & $\begin{array}{l}\text { Abdulkabir Aliu } \\
\text { Managing Director / Chief } \\
\text { Executive } \\
\text { Matrix Energy Ltd }\end{array}$ & & $\begin{array}{l}\$ 13.376 \\
\text { billion }\end{array}$ & \\
\hline 3 & $\begin{array}{l}\text { Ifeanyi Anosike } \\
\text { Group Managing Director } \\
\text { Anosike Group of } \\
\text { Companies }\end{array}$ & $\begin{array}{l}\text { Fraudulently obtained } \\
\text { money for purportedly } \\
\text { importing } 15,000 \text { metric } \\
\text { tons of PMS fuel }\end{array}$ & $\begin{array}{l}\$ 1.54 \\
\text { billion }\end{array}$ & \\
\hline 4 & $\begin{array}{l}\text { Emeka Chukwu } \\
\text { Managing Director / Chief } \\
\text { Executive } \\
\text { Dell Energy Ltd }\end{array}$ & \multirow{3}{*}{$\begin{array}{l}\text { Allegedly importing } \\
\text { 14,273,227 litres of PMS } \\
\text { fuel }\end{array}$} & \multirow{3}{*}{$\begin{array}{l}\text { N0.790 } \\
\text { billion }\end{array}$} & \\
\hline 5 & $\begin{array}{l}\text { Ngozi Ekeoma } \\
\text { Managing Director } \\
\text { Downstream Energy } \\
\text { Resources Ltd } \\
\end{array}$ & & & \\
\hline 6 & $\begin{array}{l}\text { Alhaji Adamu Aliyu Maula, } \\
\text { Managing Director, } \\
\text { Rocky Energy Ltd }\end{array}$ & & & \\
\hline 7 & $\begin{array}{l}\text { - Ngozi Ekeoma } \\
\text { Chief Executive } \\
\text { Nepal Oil \& Gas } \\
\text { - Emmanuel Morah \& } \\
\text { George Ogbonna } \\
\text { Executive Directors of } \\
\text { Rocky Energy Ltd } \\
\text { - Bamidele, Aros and } \\
\text { Bankole }\end{array}$ & $\begin{array}{l}\text { Allegedly importing } 6.65 \\
\text { million litres of PMS fuel }\end{array}$ & $\begin{array}{l}\text { N3.70 } \\
\text { billion }\end{array}$ & \\
\hline 8 & $\begin{array}{l}\text { Abiodun and Kayode } \\
\text { Directors, A\&B Investment } \\
\text { Ltd }\end{array}$ & $\begin{array}{l}\text { Taking fuel subsidy } \\
\text { payment on false } \\
\text { pretence and forging } \\
\text { documents to import } \\
\text { motor fuel }\end{array}$ & $\begin{array}{l}\$ 2.45 \\
\text { billion }\end{array}$ & \\
\hline 9 & $\begin{array}{l}\text { Senator Farouk Lawan } \\
\text { National Assembly }\end{array}$ & $\begin{array}{l}\text { Collected bribe from } \\
\text { Femi Otedola to tamper } \\
\text { House of Rep Adhoc } \\
\text { Committee probe report } \\
\text { on fuel subsidy }\end{array}$ & $\begin{array}{l}\text { M } 10.32 \\
\text { million } \\
\text { (US\$620,0 } \\
00 \text { ) }\end{array}$ & $\begin{array}{l}\text { Suspended as } \\
\text { Chairman of the } \\
\text { Adhoc Committee } \\
\text { and investigated } \\
\text { by EFCC }\end{array}$ \\
\hline
\end{tabular}

\section{Source: Excerpt from Adesomoju, Ade (2012), News Magazine, "Fuel Subsidy Scam", October} 2012, pp 12:1-3

The James Ibori's cases, former governor of Delta state, Nigeria, seems to confirm the effect of 'judicial decay' on PEC. According to Soyinka (2012:47),

The conviction of Ibori illustrates how corruption has subverted the judicial system in Nigeria. While a London Court confirmed without prevarication that Ibori had two previous convictions for petty theft in the UK, Nigerian court went through a protracted process right to the Supreme Court before concluding that one 'James Onanefe Ibori, who stole building materials... in Abuja, was different from James Onanefe Ibori', who became governor of Delta state.... While London Metropolitan Police and Crown Prosecution Services succeeded in convicting Ibori of 
money laundering, all the 170 charges against him in Nigeria were summarily dismissed by Justice Marcel Awokulehim.

Going forward, the law enforcement agencies, especially the Police and officials of the anticorruption agencies themselves are also gullible and culpable to a large extent. In fact often they are guilty of not fighting corruption and have in different times aided corruption.

The final challenge is redressing the structurally defective anti-corruption agencies, especially EFCC and ICPC. The agencies have over-bloated membership in their governing boards, with about 90 percent of their members being political - appointees. Such structural arrangement has deprived the agencies of efficiency because the politicians, who commit the crime, are also the "commanders" of the 'war against corruption'. It is probably for this reasons, Prince Lateef Fagbemi, an Ibaden-based legal practitioner, pointed out in his lecturer on 12 June 2012 to commemorate the 19th year of the annulled June 12, 1993 presidential election that:

Inspite of large numbers of fraud discovered in the public dealings, very few prosecutions are made while convictions are hardly secured against the offenders.

Notwithstanding the foregoing, the first lesson for the future is that, the war against PEC is the total and complete realization of its debilitating and harmful effects on the economic growth and development of Nigeria. "Thus, if not checked, it will provide a breeding ground for organized crimes, jeopardize the credibility of government and its institutions, and cause political instability" (Desmobak, 2003:35; Ibaba \& Okolo, 2009; Okolo \& Inokoba, 2014: 11 27; Etekpe \& Okolo, 2011: 377 - 393).

The second lesson is that the war against PEC has three basic pre-conditions:

i. A political will and commitment that goes beyond mere expression or establishment of EFCC, ICPC;

ii. A comprehensive criminal legislation that will make PEC a bit riskier for perpetrators; and

iii. An institutional framework tailor-made for the complexities and sophistication of modern time PEC.

To minimize, if not eradicate PEC and corruption in general, government has to decisively address the three conditions and translate the 'war' into action. It should do this by carrying along the elites and civil society organizations like the Nigerian Bar Association (NBA), Nigerian Medical Association (NMA), Academic Staff Union of Universities (ASUU), Judiciary and other stakeholders to play significant roles. This calls for a radical departure from the current practice where PEC cases are fought just in the minds and lips of government. The vision for a corruption-free-society must be shared by all Nigerians through a "purposeful programme of ideological persuasion and value re-orientation" (Etekpe, 2009b:231- 44; Okolo \& Etekpe, 2014:166 - 186).

The final lesson is that fighting PEC is an expensive and dangerous venture, but saves cost in the long run. Thus, to starve EFCC and ICPC of the required funds as is presently done is a demonstration of 'how not to fight corruption'. If the National Assembly, for example, required N12 million a week to probe the activities of ICPC alone, the anti-graft agencies should be funded to the tune of $\mathrm{N} 44.918$ billion per year (i.e.; 52 weeks x 36 states $\times$ N12 million x 2 agencies). 


\section{CONCLUSION AND RECOMMENDATIONS}

The paper examined six major cases (manifestations) of PEC and ascertained the identities, particulars, status and nature, as well as beneficiaries in Nigeria. The cases are: Halliburton, NNPC, sales of excess crude oil, fraudulent award of oil blocks, oil bunkering and fuel subsidy scam perpetrated by highly placed Nigerians and companies to the tune of about US $\$ 400$ billion. The paper found that corrupt practices have impacted negatively on the nation's economy and development, leading to unfunded and/or abandoned projects, such as, the four petroleum refineries in the country, rehabilitation of the East-West Road, and Escarvos Gas to Liquid Project (EGTL) that would have greatly enhanced the sustainability of development efforts in Nigeria. The negative effects of PEC are starkly demonstrated by the fact that Nigeria will largely miss all the targets of MDGs set for 2015.

This is worrisome, especially as the EFCC and ICPC are incapacitated to prosecute the 'war against PEC' because as the judiciary seems to be colluding with the perpetrators to fraudulently obtain perpetual injunctions or intermittent adjournments to frustrate diligent prosecution of cases. This trend is succeeding because in Nigeria the state and private sectors have reached the point that small group of persons who control most of the nation's wealth are the same individuals who hold the most powerful political offices in the country, although these have slightly changed between 2013 - 2014. But to say the least Nigeria needs to work hard on the paths of truth, commitment and transparency in order to get to the "promise land".

The paper has brought out three important lessons for the future. The lessons are anchored on the demand for good governance. The demand has to be a collective effort of government and civil society organizations - just the way they demanded for explanation for the fuel subsidy removal in January 2012.

Based on the analysis and discussion, the paper recommends:

i. An establishment of special courts for economic and financial crimes (corruptions) to forestall the prevailing attitude of regular courts' incessant adjournments and perpetual injunctions;

ii. Adequate funding and management of EFCC, ICPC, Police; and

iii. The National Assembly re-organize its standing committees to carry out diligent oversight/investigative functions inform of monitoring performance of Ministries, Departments and Agencies (MDAs), and holding persons accountable for their action or inaction.

\section{References}

Achike, O. (1978). Groundwork of Military and Military Rule in Nigeria. Enugu: Fourth Dimension Publishers.

Adelegan, F. (2009). Governance: An Insider's Reflection on the Nigerian Polity.Ibadan: Terrific Publishers

Adesomoju, A. (2012, October 12). Fuel Subsidy Scam EFCC, Oil Marketers. News Magazine, pp. 1-3.

Agbaegbu, T. (2012, July 23). “Indicted Companies, their Owners”, Newswatch. Pp.12-16.

Agbo, A. (2010, June 28). How the Judiciary Aids Corruption, Tell, pp. 14-18, June 28:16-18.

Ajaero, C. (2008, July 14). Oil Blocks Fraud - A Chamber of Scandals. Newswatch, pp. 14-21.

Ajanaku, L. (2012 July 16). Subsidy: Playing it Smart. Broad Street Journal, pp 34-35.

Ajani, J. (2003, January 3). The Conspiracy Theories, Vanguard, pp. 15.

Akinbi, J O. (2003). Corruption in the Politics and Economy of Nigeria: Implications for National Development. NJEH, Vols 5 \& 6:123-131. 
Aluko, 0. (1976). Oil at Concessionary Prices for Africa: A Case Study in Nigerian Decision - Making African Affairs, Vol. 75:301.

Akinkuotu, A. (2005, March 7). The Evils the British Did. Tell, pp. 33-36.

Alli, Y. (2012, August 29). Peace Moves on N2.29 Trillion Excess Crude Account. The Nation, pp. 1, 4.

Anucha, C. (2012, June 13). JTF Arrests 33 Oil Theft Suspects, Destroys 12 Illegal Refineries in Rivers, Bayelsa Daily Sun, pp. 10.

Ayandiji, D A. (Ed) (2007). Corruption and Challenge of Human Development. Lagos: Emaphine Reprographics.

Bayart, J F. (1993). The State in Africa: The Politics of the Belly. London: Longman.

Biersteker, T \& Lawis, P (1997). “The Rise and fall of Structural Adjustment Programme in Nigeria” in Diamond, L et al. Transition without End, London: Lynne Rienner.

Campbell, J. (2010)). Nigeria: Dancing on the Brink. Ibadan: Bookcarft.

Corporate Crime Reporter (2004, February 16). pp 8.

Decouty, E. (2003, December 20). “A Nigerian Contract at the Heart of Corruption Affairs”, LeFigaro, December 20.

Desmobak, S. (2003, January 3). "How not to Fight Corruption”. Vanguard, pp. 35.

Dunia, A. (2012). “Halliburton Scandal: Confession of OBJ's men, in May, David (2012). The Halliburton Scandal: Business as Usual, Internet Crime Report.

Etekpe, A. (2009a). "Policy Option and Adaptation: A Comparative Study of the Niger Delta and other Deltas of the World”. Department of Political Science, Niger Delta University, Monograph Series, No. 003.

Etekpe, A. (2009b). Citizen-Oriented Community Development Initiative: A New Model for Peace-Building in the Niger Delta. African Journal of Economy and Society, Vol. 9 (1 \& 2).

Etekpe, A. (2009c). “The Niger Delta Development Commission (NDDC) and Peace Building in the Niger Delta” National Development Studies, Vol.1 (1), April; pp 26-42.

Etekpe, A. (2012). “External Debt Management and Development Issues in Nigeria, 1998-2009” Monograph Series No. 07 Department of Political Science, Niger Delta University, Bayelsa state, Nigeria.

Etekpe, A. \& Okolo, P. O. (2011). The challenges and Prospects of Sustainable Rural Development Programs in Bayelsa State of Nigeria, 1999 - 2009. International Journal of Development Studies, Vol. 3, No. 2, (2011). ISSN 2141-8713, Center for the Promotion of International Relations, Studies and Development, Kandid Gold, Accra Ghana. Www.ccsdev.org. Pp. 377 - 393

Etekpe, A. \& Okolo, P. O. (2012). International Court of Justice (ICJ) Judgment on the Bakassi Penisula and Lake Chard: Litmus Test for Peace and integration in Africa. In Albert, I. O; Eselebor, W. A. \& Danjibo, N. D. (Eds) (2012). Peace, Security and Development in Nigeria. Ibadan. John Archers Publishers Ltd. Pp. 509 - 524

Ezekwesili, 0. (2012). "Corruption, National Development, Bar and Judiciary”. A Paper presented at the 52nd Annual General Conference of the Nigerian Bar Association, Abuja, and August.

Fatogun, D. (1979, August 31). Effects of Capitalist Rationalisation on Workers. World Marxist Review, Vol. 4 (1), August 31: xi - xiii

Henley, J. (2003, October 11). French Sleaze Inquiry Targets US Oil Subsidiary. The Guardian, pp. 15.

Houston Chronicle (2004, February 22).

Human Rights Watch (1999). “The Price of Oil”. New York: HRW

Ibaba, I. S. (2013). “Is Nigeria A Failed State?” Monograph Series 08, Department of Political Science, Niger Delta University, Bayelsa state, Nigeria.

Ibaba, S.I. \& Okolo P.O. (2009). "Resolving Militia conflicts in the Niger Delta: The Role and strategies of Mediation, Martins papers, Martins Institute Article 2:

http://www.class.uidaho.edu/martin_archives/Martin\%20Papers.html

Isakpa, Philip (2013). “Global Corruption Barometer 2013”. Business Day, July 15; 52-3 
Jega, M., (Ed) (2005). Corruption: The Trouble with Nigeria - Discharging a Burden. Proceedings of the 3rd Media Trust Annual Dialogue Lagos: Media Trust Ltd.

Komolafe, B. (2012, October 24). "Nigeria's Foreign Trade Drops by 50\%" October 24:2

Kumolu, C. (2009, October 7). Millennium Development Goals: The Crack and Mortal Blows Ahead of Nigeria. Vanguard, pp. 39.

Nkechi, Onyedika (2013). “Government Loses US\$1 trillion Yearly to Corruption” The Guardian, August 14:16 Ogundele, K \& Unachukwu, A J. (2012, August 29). US\$400 billion Oil Money Mismanaged by Government. The Nation, pp. 61.

Okolo, P. O. \& Akpokighe, O. R. (2014). Corruption in Nigeria: The Possible Way Out, Global Journal of HumanSocial Science: F Political Science, Vol. 14(7), pp. 30 - 38

Okolo, P. O. \& Akpokighe O. R. (2014). Federalism and Resource Control: The Nigerian Experience. Journal of Public Policy and Administration Research, Vol. 4, No 2, (2014). IISTE USA.

http://www.iiste.org/journals/index.php/PPAR/article/view/11092. Pp. 99 - 109.

Okolo, P. O. \& Etekpe, A. (2011). A study of Public Maintenance Culture and its Impacts on the Socio-Economic Development of Nigeria, 2005 - 2009. International Journal of Development Studies, Vol. 3, No. 2, (2011). ISSN 2141-8713, Center for the Promotion of International Relations, Studies and Development, Kandid Gold, Accra Ghana. Www.ccsdev.org. Pp. $29-46$.

Okolo, P. O. \& Etekpe, A. (2014). Value Re-Orientation: Policy Option for Sustainable Development in the Niger Delta. Journal of Sustainable Development in Africa, Vol. 16(6), pp. 166 - 186

Okolo, P. O. \& Inokoba, P. K. (2014). “Democracy and Resource Conflict Resolution: Making a Case for the Democratic Solution to the Niger Delta Crisis". International Journal of Development and Emerging Economics. Published by European Centre for Research Training and Development UK (www.ea-journals.org) Vol. 2, No. 2, Pp. 11 - 27, June, 2014.

Okolo, P. O., Opukri, C. O., Osimerah, C. A. \& Max-Egba, K (2014). Nigerian Political Parties and Patron - Clientele Syndrome. Journal of Sustainable Development in Africa, Vol. 16(5), 102 - 118

Okolo, P. O. (2014). Managing Minority Problems in Nigeria: The case of the Ethnic Minorities of the Niger Delta Region. Journal of Economics and Sustainable Development, Vol. 5, No. 6, (2014). ISSN 2222-1700 (Paper) ISSN 2222-2855 (Online). IISTE USA. http://www.iiste.org/journals/index.php/JEDS/article/view/11938 or www.iiste.org. Pp. 91 - 99.

Okolo, P. O. (2014). NDDC, Conflict, Peace - Building and Community Development in the Niger Delta Region, Global Journal of Political Science and Administration, Vol. 2, No. 1, pp. 36 - 51, March 2014 - Published by European Centre for Research Training and Development, UK. (www.ea-journal.org)

Okolo P. O. (2011). Federalism: Theory and Evidence A comparative perspective. Lagos: The Bleek Integraed Service press.

Olawuni, Tunji (2013). “Fuel Emporters yet to be paid from N971.138 billion Subsidy Budget”. Business Day, June 09:6

Onabanjo D. (2009, October 12). From Boom to Burst. Tell, pp. 58-59

Richburg, K B. (2004, January 24). “French Judge Probes Unit of Halliburton”. Washington Post.

Soyinka, A. (2012, May 28). “Why the Corrupt are Winning”. Tell.

Ujomu, P O. (2000). The Economy, Resource Management and the Maintenance of National Security in Nigeria: A Critique of the Shagari, Babangida and Abacha Regimes. The Nigerian Journal of Economic History, Vol. 3(90).

United Nations (1998). United Nations Human Development Report. New York: Oxford ～University Press. USCR78dd-1, 78dd-2-3.

Uwugiaren, I. (2004, November 8). Olusegun Obasanjo and the Russian Pirates. Insider Weekly, pp. 28-30.

WAC Global Services (2003). "Peace and Security in the Niger Delta: Conflict Expert Group Baseline Report”. Brussels: SPDC Working Paper, December. 